\title{
Students' experiences about PBL as theylearn Developmental Mathematics at a Higher Education Institution in Trinidad and Tobago: A qualitative case study
}

\begin{abstract}
This action research highlights the experiences of undergraduate students who studied Developmental Mathematics using the Problem-Based Learning(PBL) strategy. They were exposed to fifteen weeks intervention at a Higher Educationinstitution in Trinidad and Tobago called HilltopCollege. A review of the existing literature within the local context indicated that there is a paucityof information about theirexperiences. Consequently, their experiences are critically important since they can be an impetus for the formulation of policy and implementation towards the teaching/learning of Developmental Mathematics inthis country. Thus, it is absolutely necessary that policy makers heed the voices of these students especially when they are formulating curriculum that pertain to Developmental Mathematics. A qualitative case study was conducted to carefully ascertain their experiences and answer the research question: What are students' experiences with Problem-Based Learning in the study of Developmental Mathematics at Hilltop College? Twenty-four students participated. A structured questionnaire and semi-structured interviews were utilized with four focusgroups. Data were analyzed under six major headings: Approach to teaching, social relationships, resources, pace of teaching, emotional intelligence and the role of the teacher. Recommendations strongly advocating that student-centered strategies be employed when studying Developmental Mathematics were also offered.
\end{abstract}

KEYWORDS: Developmental Mathematics, Problem-Based Learning

Students' experiences about PBL as theylearn Developmental Mathematics at a Higher Education Institution in Trinidad and Tobago: A qualitative case study

\section{Introduction}

According to The Caribbean Secondary Education Certificate (CSEC) Council (cxc.org, 2018), there is a decline in the performance of students at the General Proficiency Grades I to III for studentswho studyMathematicsin Trinidad and Tobago. It must be carefully noted that in January 2017thirty-six percent of the candidates achieved a pass grade as compared to January 2018 where a mere thirty percentwas successful. This statisticis a clear indication that some of these students are likely to enter the higher education sector without a solid foundation in Mathematics skills. Hence, it is imperative that they getthe necessary assistance if they are to be successful with higher education Mathematics credit courses.

This implies that the administration ofHilltop College oughtto provide adequate support for these students who are willing to pursue higher education programmes. Students must be afforded with an equal opportunity to enhance their Mathematics competencies. Without this necessary intervention, many of them will spend a longer time studying Mathematics and may not even achieve their goals.Policy makers at Hilltop College seldom incorporatethe voices of students.This is even more accentuated especially among those who study Mathematics. Thus, it is imperative that administrators listen conscientiously to their voicesas they experience this support. Their voices can be used to create effective Developmental Mathematics programmes. In addition, their voices can assist the administration in formulating newand relevant teaching/learning programmes. These programmes must be student-centered and create a non-threatening environment so that students will be motivated to study Mathematics.

Although the voices of students are absolutely necessaryin the formulation of policy, they were never documented. Hence, this paucity of information on students' learning experiences led to this action research. Students were exposed to the use of ProblemBased Learning (PBL) strategy for the duration of their study of Developmental Mathematics over fifteen weeks. They were very willing and quite eager to forgo their traditional teaching/learning strategy infavourof this new approach.

Thispaper focuses on vicarious experiences of students who entered Hilltop College without the matriculation requirement of a pass in O'level Mathematics (General Proficiency, Grades I-III). They took the traditional diagnostic test in Mathematics and did not even attain 50\%. The practice at the Hilltop College is that these students read a Developmental Mathematics course to help them to acquire the necessary skills and content to pursue creditable Mathematics courses. Thus, this research answered the question: Whatare students' experiences with the PBL approach to the study of Developmental Mathematics at the Hilltop College?In the following sections the term developmental education was clearly expounded and PBL was explained. The methodology wasoutlined. Data collection and analysis processeswere also 
Students' experiences about PBL as theylearn Developmental Mathematics at a Higher Education Institution in Trinidad and Tobago:

A qualitative case study

described. Findings were narrated with sixmajor themes and recommendations were offered.

\section{LITERATURE REVIEW}

II.I Developmental Education: A variety of support services provided to students who would not have acquired the matriculation requirement is called developmental education (Sole, 2020). Students who enter tertiary education institutions without the matriculation requirement normally require developmental education to assist them with the rigor of higher education (Bonham \& Boylan, 2012). Developmental is a term that refers to courses in which students enroll to prepare them for credit level Mathematics classes, which they will meet in their programmes. The provisionsof Developmental Mathematics at the higher education institutions are aimed at assisting students in gaining basic mathematical cognitive skills.Further, developmental education was designed to strengthen students' academic skills, and prepare them to be more successful in every-day activities which require Mathematics skills andalsoGeneral Education Mathematics courses.

Developmental Mathematics education is still a major issue among many educators. Although theaim of Developmental Mathematics education at highereducation institutions is to assist students in acquiring and applying basic mathematical skills; the literature states that these classes prevent them from attaining their educational goals (George \&Milman, 2019) and theygraduate at a later date than they anticipated (Chen \& Henke, 2017). Since Developmental Mathematics education is a concern among both educators and students,reform in development education is urgently needed. This paper documentsstudents' first experience with the PBL strategy in the study of Developmental Mathematicsat Hilltop College. The research question helped to capture their opinions and maintain the perspective. Thefollowing segment provides an explanation of PBL.

II.II Problem-Based Learning (PBL): Barrows and Tamblyn (1980) together with Kim (2019) posited thatProblem-Based Learning (PBL) was first coined in 1969 at the Mc Master University in Canada. It was originally developed to increase problem solving skills among medical students (Barrows, 1983). Murphy (2009) states that it is fundamentally grounded in constructivism, which is a 20th century philosophical approach. Constructivism is chiefly based on the premise that knowledge is constructed through interactions among a group of learners. This ought to be done through proper collaboration among peers in pursuit of the solution of original real-world problems (Cantürk-Günhan, Bukova-Güzel, \&Özgüranese, 2012).PBL represents a distinct andcomplete shift in the education process. Arul (2007) and Schmidt (1983),posited that it involves a radical moving away from the traditional instructional approach. This characteristicheavily focused on the instructor and placed very little attentionon the student.

BoudandFeletti (2003) together with Barrows (1996), stated that this new student-centered approach offers six distinctive features: authentic experiences, learner centeredness, selfdirected learning, problem solving skill development, group work and the changing role of teachers as facilitators.Authentic experiences assist students in comprehending the context within which the knowledge is to be applied. Thecore of this learning processinvolves a deliberate and conscious attempt by the students to find solutions to the given ill-defined problems. For example, the lecturer begins the PBL procedure by presenting a real-world problem. This initiative stimulates dynamism, provokes cognition, and motivates students to pursue solutions to the open-ended and ill-defined problem (Boud\&Feletti, 2003; Wijnen et al., 2018).

PBL is executed with students planning, investigating, allocating responsibilities, reporting and occupying the centre of the classroom with their learning strategies (Barrows, 1996; Kim \& Tan, 2013). Students engage in multiple activities through researching and analyzing materials. They discuss content matterand communicate with their peers and teachers to solve the authentic problems. Hence, they are meaningfully occupied throughout the PBL procedure (Kim \& Tan, 2013).

Self-directed learningensures students take responsibility for their own learning (Boud\&Feletti, 2003; Cantürk-Günhan et al., 2012). Students are engaged in activities to enhance their own learning of content matter. However, they must be aware of their knowledge gaps and own limitations. They also need to accumulate all possible information necessary. This includes their wealth of experiences as well as all learning, and skills gathered from other programmes of study. In addition, they must engage in relevant research to gather pertinent information and thus, solve the problem.

In designing PBL modules, the facilitator must be cognizant of including problem solving competencies. Modules must be relevant to students' experiences, challenging in various levels of difficulty and engaging (Dole, Bloom \& Doss, 2017). Previous studies recorded the potential for PBL to develop higher orderthinking skills such as comprehension, analysis and application of knowledge (Allen, Donham \& Bernhardt, 2011; Jerzembek\& Murphy, 2013).

Group work encourages and motivates students to actively engage with their peers. Sungur and Tekkaya (2006) reported PBL encourages peer learning. This social interaction coupled with the intellectual inquiry facilitates camaraderie which is an essential ingredient of the PBL strategy.In doing so they freely express their opinions and ideas. Learning becomes dynamic and engaging and thus, cognition is evident (Cantürk-Günhan, et al., 2012).

The final criteria espoused by Boud and Feletti (2003) 
Students' experiences about PBL as theylearn Developmental Mathematics at a Higher Education Institution in Trinidad and Tobago:

A qualitative case study

together with Barrows (1996), is that the teacher's role becomes a facilitator. Initially the teacher's role is to fully explain the problem, concepts and procedures that students are required to acquire. The teacher's role then changes to the facilitator who critically monitors students' activities of researching and solving problems.

This student-centered approach underscored by Patankar (2011) and UNESCO (2000; 2011), is a direct result of innovation and research through educators who had a keen interest in promoting best practices at higher education. The call to implement student-centered education was accepted globally. Traditional education which tend to stereotype students as 'surface' learners was also questioned (Drinkwater \& Smethurst, 2011; Patankar, 2011; Watts \&Schaur, 2011). The numerous calls for changes in instructional approaches caused international investigations into the learning styles and classroom behavior of students. Some studies have concluded that students portray themselves as mainly a homogeneous group of passive learners who rely on rote learning and memorization (Mergendoller et al., 2000; Patankar, 2011). They lack critical thinking skills and are not “deep learners" (Patankar, 2011, p. 24). Darling-Hammond (2013) clearly highlighted that classroom instruction and improvement in teaching are receiving increased attention in colleges and universities worldwide. Moreover, researchers have reported that the study of Economics discouraged cooperation among students, who tend to prefer to work on their own, rather than in groups, in order to understand and clarify difficult concepts (Iida \& Oda, 2011; Mergendoller et al., 2000). Hence, these and other findings should be tested via studies in the local context.

\section{METHODS AND PROCEDURE}

III.I Qualitative research: A qualitative approach which involved a case study, a structured questionnaire and semi-structured interviews were utilized. The use of a structured questionnaire and semi-structured interviews provided a clearer understanding of the experiences of these twenty-four students. Questionnaires and interviews were carefully chosen because it was felt that they would allow students to speak freely and thus, address the research question: What are students' experiences with Problem-Based Learning in the study of Developmental Mathematics at Hilltop College? This action research involves a cyclical process of data collection, analysis and reflection. Leedy and Ormrod (2018) and Tewksbury (2009) mentioned that qualitative research provides indepth and detailed information as well as it explores issues within participants' particular scenario. Meyer (2000) maintained that the strength of action research lies in its focus on generating solutions to practical problems. Moreover, it empowers practitioners, by getting them to actively participate in the research (Merriam \&Tisdell, 2016). Reason and Bradbury (2006) described action research as an approach that is used in designing studies and it also seeks both to inform and influence practice. Creswell (2018) alluded to the fact that qualitative research is useful because researchers can explore and comprehend in greater detail what respondents convey.Four demographic items were used to collect data and answerthe research question. These were recorded into categorical variables for further analysis. The selected criteria examined: age range, gender, marital and employment status. Data collection was done through regular and consistent fieldwork. The days and the hours of contact were deliberately chosen to accommodate the students.

III.II Case Studies: They are holistic inquiries that seek to investigate a specific phenomenon within its natural setting (Creswell, 2012). They are suitable for description, explanation, and exploration into arbitrary issues. According to Yin (2009) case studies explain, describe, illustrate, and enlighten. Yin (2009) also stated that they are empirical investigations and are chiefly based on knowledge and experiences. They are also apt methods of qualitative research that intensely investigate a particular phenomenon within a specific context. In a similar way, Smith (1978, cited in Merriam \&Tisdell, 2016) posited that case studies are versatile and dynamic and provide a thorough and detailed examination of a phenomenon. They arealso an intensive, holistic description and analysis of a single unit. Thus, Cohen, Morrison and Manion (2018) described them as an inquiry into precise scenarios within a real-life situation.

III.III Structuredquestionnaires: Miles and Huberman (1994) stated that questionnaires give students an opportunity to freely express their voices in a dataset. They are cost effective, and efficient ways to collect information on a specific topic from a sample of people (McMillan, 2016). Therefore,structured questionnaires wereselected as an apt method to conduct this research. They were also chosen because it was felt that the Likert type questions, would enable participants to answer specific questions to the under investigation.

A self-designed questionnaire elicited demographic data and generalized information from students.Through the use of the Likert type questionnairesthe following information was also generated:students' reasons for entering their programmes, the extent to which they agreed or disagreed with tenets of PBL and thedegree to which students' learning styles were accommodated within the investigation.

It ought to be noted that Cohen, Morrison and Manion (2018) together with Leedy and Ormrod (2018) mentioned that researchers must be acutely mindful of the advantages and limitations of the use of questionnaires. In addition, Cohen, Morrison and Manion (2018) cautioned that this instrument does not afford participants the opportunity to explain their responses and the categories might not include all that they might want to say. Thus, semi-structured interviews addressed that deficiency and simultaneously served to 
Students' experiences about PBL as theylearn Developmental Mathematics at a Higher Education Institution in Trinidad and Tobago:

triangulate data.

III.IV Semi-structured interviews: To capture a clearer understanding of the experiences of these students, semistructured interviews were used. Theywere carefully selected because researchers felt that they would allow students to speak without inhibition and thus, address the research question: What are students' experiences with Problem-Based Learning in the study of Developmental Mathematics at Hilltop College?Thus, semi-structured interviews were chosen because they allowed researchers to explore experiences among the four focus groups of students.

Semi-structured interviews allowed students to communicate spontaneously (Evans, 2018). In addition, researchers were also able to interact directly with them and thus seek clarification with follow-up questions. They also allowed researchers to gain information from verbal and non-verbal responses. In this way researchers were able to comprehend the nuances which added a deeper level of meaning.

During the interview process, notes of the various responses of students were documented immediately. Interviews were also transcribed as soon as they were completed. This was deliberatelydoneto improve accuracy and maintain the integrity of the data collected (Creswell, 2018).

III.IV.iReliability: Pilot and Beck (2014, cited in Connelly, 2016) hold the firm view that reliability in qualitative studies refers to the level of confidence in the data, interpretation, and methods used to support the quality. Additionally, Leung (2015) stated reliability in qualitative research refers to exact replicability of the processes and the results. Thus, to enhance consistency, intercoder reliability was established. Independent coders matched their statements after analyzing their findings and found that individually, they had the same codes. A high level of intercoder reliability indicated that both reliability and replicability were present, and this strengthened evidence that the results of a qualitative study were scientifically valid (Kurasaki, 2000, cited in Mac Phail et al, 2016, p. 199).To maintain this high level of reliability, responses from semi-structured interviews and questionnaires were properly recorded and clearly documented.

III.IV.iiValidity: Creswell (2018) noted that credibility is evident when researchers validate their findings. According to Denzin (1978, cited in Danny, 2014) triangulation is the use of more than one method to gather data, such as informal interviews, and semi-structured questionnaires. Creswell (2012) offered that triangulation is also the process of corroborating evidence from different individuals in descriptions and themes in qualitative research. Similarly, Spaulding (2014) and Walsh (2013) observed that triangulation presents different aspects and a detailed analysis of the research outcome. Triangulation also allowed the researchers to collect and compare various perspectives of the phenomenon so that data presented were reliable,valid and free from bias. It further allowed them to optimize credibility.

\section{FINDINGS}

\section{IV.I The Students}

As noted in the introduction, students were exposed to the (PBL) strategy for five weeks, with three sessions per week. Illdefined questions guided their study over five modules. At the end of the intervention, they completed a structured questionnaire with interval-scales(Stoute, 2010) and engaged in semi-structured interviewswith four focus-groups.

All students participated willingly in the discussionsand information was collected from four groupsofsix students each. The group memberships for the class PBL training sessions were maintained for the focus group discussions. Demographic categorical variables of students were highlighted.The demographic frequency distributions are carefullydetailed in Table 1 . The sample was predominantly female $(58.3 \%)$, within the age group of $26-35$ years $(66.7 \%)$, mostly single $(79.2 \%)$, and almost all employed (91.7\%). Most of the participants were single, between the ages of 26-35 years, employed andwere still pursuing their higher educationwhich beganwith studies in Developmental Mathematics.

Table 1: Demographic data for PBL intervention in Developmental Mathematics

\begin{tabular}{|c|c|c|}
\hline DEMOGRAPHIC & CATEGORY & FREQUENCY (\%) \\
\hline \multirow{4}{*}{ GENDER } & Male & 41.7 \\
\cline { 2 - 3 } & Female & 58.3 \\
\hline \multirow{4}{*}{ AGE } & Younger than 25 Years & 16.7 \\
\cline { 2 - 3 } & & \\
\cline { 2 - 3 } & 25 to 35 years & 66.7 \\
\cline { 2 - 3 } & 36 to 45 years & 12.5 \\
\cline { 2 - 3 } & 46 to 55 years & 0 \\
\hline \multirow{5}{*}{$\begin{array}{c}\text { EMPLOYMENT } \\
\text { STATUS }\end{array}$} & E6 years and older & 4.1 \\
\cline { 2 - 3 } & Employed & 91.7 \\
\hline \multirow{2}{*}{$\begin{array}{c}\text { MARITAL } \\
\text { STATUS }\end{array}$} & Single & 8.3 \\
\cline { 2 - 3 } & Married & 79.2 \\
\cline { 2 - 3 } & Divorced & 12.5 \\
\hline
\end{tabular}

As mentioned above students at Hilltop College who gained entry into theAssociate Degree programme without matriculation qualificationswere required to do diagnostictestsin both English Language and Mathematics. Those who participated in the diagnostic test in Mathematics and got less than 50\% were selected to pursue Developmental Mathematics. This mark was considered 
the pass rate for the diagnostic test because the constructors felt that it represented sufficient capability in the basic skills that students needed to pursue their academic studies successfully. Twenty-four (24) students were identified and recommended for the Developmental Mathematics course and they also participated in the PBL intervention. Classes were conducted at Hilltop College on Monday, Tuesday and Wednesday. from 5:00 p.m. to 8:00 p.m.Additional classes were held on Saturday from 9:00 a.m. to 12:00 p.m. for sessions that were lost.The attrition rate was zero.

IV.II Analysis of data: It was a challengeto analyze the experiences of these students. This is because their ideas were complex accounts and could be best understood within their particular context. In addition, some of their perspectives were often couched in profound stories. To analyze data, researchers had to consider the form and context of these voices. To a great extent this involvedscrutinizinghow students conveyed their own experiences. Thus, researchers reviewedspecific words, sentences, and linguistic features. They also paid particular attention to the way in which certain "slangs" were used. Furthermore, researchers were very attentive when phrases were spoken, why they were mentioned, and how they were said within the social context. In this manner they were able to arrive at a comprehensive understanding of the experiences of these twenty-four undergraduate students.

The analysis was documented in a narrative form. It also used appropriate examples and jargons from the data to further clarify issues. This was deliberately done to highlight the relationship between the analysis and the given context. It is important to mention that this narrative represents the voices of these students. It is documentedwith the use of six major components:Approach to teaching, social relationships, resources, pace of teaching, emotional intelligence and the role of the teacher.

Approach to teaching:During the focus groups discussionsabout PBL and Developmental Mathematics the students mentionedthat they were eager and excited about this new approach to teaching and provided positive feedback to the questionnaire and interviews. Theyunanimously acclaimed that they "enjoyed" this approach since it fostered "self-directed learning." They "liked problems" and "did not mind this way of teaching"because it "showed them how to read" and often "forced them read." Bonham and Boylan (2012) stated that students involved in meaningful Developmental Mathematics experiences stayed with the programme and were less inclined to drop out of high school. With well-structured learning experiences, students were motivated to continue with their learning experiences and courses of study.

Social relationships: Students formed professional relationships through their interactions in groups. Data revealed that they affirmed phrases associated with the PBL strategy such as: "learnt to listen" and "listened to learn from one another." This trend was commented by Howard and Whitaker (2011). Students' activities in the PBL approach to learning were also varied. They had different ways to solve authentic problem and they were given tasks to present the solution to a genuine problem via an oral presentation or a portfolio. Varying activities encouraged students to interact with each other. As a consequence, this approach further stimulated social relationships since some students, "developed leadership roles" and "learnt how to interact with peers," because they "developed respect for others'opinions."

Resources: Students used online facilities, their computers, textbooks, teachers and any other form of resources they found to assist them with the understanding of Developmental Mathematics class. The PBL approach lends itself to students seeking alternative forms of resources to assist them with solving their problems (Stearns et al., 2012). These resources aided in students' greater understanding of the course content in this experiment.

Pace of teaching: Although students stated that they preferred therelaxed and enjoyable pace of instruction offered by PBLand admitted thatit was more time consuming they had a deeper understanding of the material when they completed their readings. Students began their learning experiences with an ill-defined question posed by the lecturer. They engaged in group work to determine what they knew and what they did not know. They proceeded to allocate different aspects of the ill-defined problem for different persons to research and report. During the focus group interviews, students reported that they enjoyed the informal ways they were encouraged to collaborate and solve problems.

Emotional intelligence: Some students stated that their lack of motivation to learn Mathematics was based on their previous experiences. They also reported that, in previous Mathematics classes at secondary schools, they dropped out of the course of study or did not go to classes, because they were bored. However, during the focus group discussions, students from the PBL group reported a significant positive change of their confidence in doing developmental Mathematics. They were motivated and energized. Moreover, they wanted to attend sessions and they learnt to accept different ideas from their peers. This was observed as well in the study by Howard and Whitaker (2011). These are some of their voices:

- Assisted me in developing confidence in doing Mathematics

- Motivated me to do Mathematics

- $\quad$ Learnt to accept different ideas from my peers

- Experiences made me want to continue with the programme

- Enjoyed positive feedback from the teacher. 
Students' experiences about PBL as theylearn Developmental Mathematics at a Higher Education Institution in Trinidad and Tobago:

Role of the teacher: An outstandingaspectemanating from students' discussions was "the role of the teacher." They categorically stated that the teacher motivated and encouraged them to such degree that they thoroughly enjoyed the sessions. Furthermore, they always received positive feedback from the teacher. This feedbackproved to be extremely resourceful and useful since it assisted them to understand "hard" topics.Stearns et al. (2012) stated that the behavior of teachers in the classroom, namely the instructional approaches they employ, "significantly affect the degree to which students learn" (p. 10). Research has shown that ineffective Mathematics teachers can depress student achievement by as much as 54\% regardless of student abilities (Van Tassel-Baska, Quek \& Feng, 2007). These voices provide an apt conclusion:

- $\quad$ Enjoyed positive feedback from the teacher

- Resourceful

- Too fast in teaching for me to understand graphs

- Makes learning easy

- Very supportive

- I enjoyed the interaction with the teacher

- The teacher was approachable when I had problems.

\section{CONCLUSION}

This qualitative case study conducted among twenty-four students allowed researchers to carefully ascertain their experiences with Problem-Based Learning in the study of Developmental Mathematics at Hilltop College.Action researchafforded researchers the great flexibility to interact informally with these undergraduates in their natural environment. Furthermore, it allowed the students to speak freely and openly about their firsttime experiences of the PBL strategy. A questionnaire and semistructured interviews assisted researchers to maintain the focus and thus answer the research question. Data were collected, collated, and documented in a narrative form using sixbasic headings: Approach to teaching, social relationships, resources, pace of teaching, emotional intelligence, and the role of the teacher. It was a challenge to analyze the experiences of these students. This is because some of their perspectives were often couched in profound stories. The researchers listened attentively and were able to properly comprehend their varied experiences.

\section{RECOMMENDATIONS}

From the foregoingthe following recommendation is made.

Students at higher education institutions should be properly exposed to student-centered teaching strategies such as PBL.
Policy makers ought to heed the voices of students.

\section{CONFLICT OF INTERESTS}

Authors have no conflict of interests.

\section{REFERENCES}

Allen, D. E., Donham, R. S., \& Bernhardt, S. A. (2011).Problembased learning. New Directions for Teaching andLearning, 2011(128), 21-29.

Arul, K.S. (2007). Making sense of Economics: Designing educational scenarios for Problem Based Learning. Paper presented at the conference organized by the University of Wales Ins. Cardiff in collaboration with the Higher Education Academy.

Barrows, H.S. (1983). Problem-based, self-directed learning. Journal of the American Medical Association, 250, 3077-3080.

Barrows, H. S.,\& Tamblyn, R. N. (1980). Problem-Based Learning: An approach to medical education. Springer Publications.

Bonham, S. B.,\& Boylan, H. R. (2012). Developmental Mathematics: Challenges, promising practices, and recent initiatives. Journal of Developmental Education, 36(2), 15-21.

Boud, D. \&Feletti, G. I. (2003). The challenge of problem-based learning ( $2^{\text {nd }}$ ed.). Kogan Page.

Cantürk-Günhan, B., Bukova-Güzel, E., \&Özgür, Z. (2012). The prospective mathematics teachers' thought processes and views about using Problem-based learning in statistics education International Journal of Mathematical Education in Science \& Technology, 43(2), 145-165. doi:10.1080/0020739X.2011.592611.

Caribbean Secondary Education Certificate (CSEC) Council. (2018). Online report of students' performances. Retrieved 18 September 2020 from cxc.org.

Chen, X., \& Henke, R. (2017). Not completing remedial courses threatens students' prospects for success in college and beyond. The Evollution. https: //evolution.com/attracting-students/ accessibility/not-completing-remedial-courses-threatensstudents-prospects-for-success-in-college-and-beyond/.

Cohen, L., Morrison, L., \& Manion, L. K. (2018). Research methods in education ( $8^{\text {th }}$ ed.). Routledge.

Connelly, L. M. (2016). Trustworthiness in qualitative research. Understanding Research, 25(6). https://pdfs.semanticscholar.org/ b467/089d0422a83fe1d5715d837dd39d9fce4e7c.pdf

Creswell, J. W. (2012). Educational research: planning, conducting, and evaluating quantitative and qualitative research (4th ed.). Pearson.

Creswell, J. W. (2013). Qualitative inquiry \& research design: 
Students' experiences about PBL as theylearn Developmental Mathematics at a Higher Education Institution in Trinidad and Tobago: A qualitative case study

Choosing among five approaches (3 ed.). Sage Publications.

Creswell, J. W. (2018). Research design: Qualitative, quantitative, and mixed methods approaches ( $5^{\text {th }}$ ed.). SAGE.

Danny, G. (2014). Triangulation in qualitative research podcast: short version. https://www.youtube.com/ watch? $=$ aTEbA2LZaIg

Darling-Hammond, L. (2013). Getting teacher evaluation right: What really matters for effectiveness and improvement? Teachers College, Columbia University.

Dole, S., Bloom, L., \& Doss, K.K. (2017). Engaged learning: Impact of PBL and PjBL with elementary and middle grade students. The Interdisciplinary Journal of Problem-Based Learning, 11(2). Retrieved at: https//doi.org/10.7771/1541-5015.1685

Drinkwater, D.,\& Smethurst, J. (2011). Partnership Now: A Paradigm Shift in Education. Independent School, 70(3), 41-46.

Evans, C. (2018). Analysing semi-structured interviews using thematic analysis: Exploring voluntary civic participation among adults.Sage Publication Ltd. http://dx.doi. org/10.4135/9781526439284

George, M., \&Milman, Y. (2019). Quantitative literacy: Alternative pathway for College Developmental Mathematics students. Journal of Mathematics Education at Teachers' College, 10(2), 29-35

Howard, L.,\& Whitaker, M. (2011). Unsuccessful and successful Mathematics Learning: Developmental Students' Perceptions. Journal of Developmental Education, 35(2), 2-16.

Iida, Y.,\& Oda, S. H. (2011). Does economics education make bad citizens? The effect of economics education in Japan. Journal of Education for Business, 86, 234-238

Jerzembek, G., \& Murphy, S. (2013). Anarrative review of problembased learning with school-aged children: Implementation and outcomes. Educational Review, 65(2), 206-218.

Kim, Y. J. (2019). Observational Application Comparing Problem-Based Learning with the Conventional Teaching Method for Clinical Acupuncture Education. Evidence-Based Complementary \& Alternative Medicine (ECAM), 1-6. doi. org/10.1155/2019/2102304

Kim, M., \& Tan, H. (2013). A collaborative problem-solving process through environmental field studies. International Journal of Science Education, 35(3), 357-387.

Leedy, P. D., \& Ormrod, J. E. (2018). Practical Research: Planning and Design (12th ed.). Prentice-Hall Inc.

Leung, L. (2015). Validity, reliability and generalizability in qualitative research. Journal of Family and Medical Primary Care, 4(3), 324-327. doi: 10.4103/2249-4863.161306
Mac Phail, C., Khoza, N., Abler, L., \& Ranganathan, M. (2016). Process guidelines for establishing intercoder reliability in qualitative studies. Qualitative Studies, 16(2), 198-212. doi: 10.1177/1468794115577012.

Mc Milan, J. (2016). Fundamentals of educational research $\left(7^{\text {th }}\right.$ ed.). Pearson.

Mergendoller, J. R., Maxwell, N. L., \&Bellisimo, Y. (2000). Comparing problem-based learning and traditional instruction in high school Economics. Journal of Educational Research, 93(6), 374-382.

Merriam, S. B., \&Tisdell, E. J. (2016). Qualitative research: A guide to design and

implementation (4 ${ }^{\text {th }}$ ed.). Jossey - Bass.

Meyer, J. (2000). Using qualitative methods in health-related action research. BritishMedical Journal, 320, 178-181.

Miles, M. B., \&Huberman, A. M. (1994). Qualitative data analysis: An expanded sourcebook. ( $2^{\text {nd }}$ ed.). Sage.

Murphy, M. M. (2009). The history and philosophy of education: Voices of educational pioneers. Pearson Education.

Patankar, P. (2011). Teacher Education: Need of Paradigm shift from Behaviorism to Constructivism. Indian Streams Research Journal, 1(11), 23-25.

Reason, P., \& Bradbury, H. (2008). The SAGE Handbook of Action Research: Participative Inquiry and Practice (2nd ed.). SAGE.

Robson, C. (2002). Real world research (2nd ed.). BlackwellCaribbean.

Schmidt, H. G. (1983). Problem-based learning: Rationale and description. Medical Education, 17(1), 11-16.

Sole, M. A. (2020). Streamlining Time spent in Alternative Developmental Mathematics Pathways: Increasing Access to College-level Mathematics Courses by Altering Placement Procedures. Journal of Mathematics Education at Teachers College, 11(1), 43-54.

Spaulding, D. T. (2014). Program evaluation in practice: Core concepts and examples for discussion analysis (2nd ed.). JosseyBass.

Stearns, L. M., Morgan, J., Capraro, M. M. \& Capraro, R. M. (2012). A teacher observation instrument for PBL classroom instruction. Journal of STEM Education, 13(3), 7-16.

Stoute, V. (2010). Lecture notes in Advanced Research Methodology. University of Trinidad and Tobago.

Sungar, S., \&Tekkaya, C. (2006). Effects of problem-based learning and traditional instruction on self-regulated learning. The Journal of Educational Research, 99(5), 307-318. 
Tewksbury, R. (2009). Qualitative versus Quantitative Methods: Understanding Why Qualitative Methods are Superior for Criminology and Criminal Justice. Journal of Theoretical and Philosophical Criminology, 1 (1).

UNESCO. (2000). Final Report. World Education Forum. Senegal. UNESCO. www.unesco.org

UNESCO. (2011). Education for Sustainable Development in the Caribbean: An assessment of the progress made in ESD as of 2011. UNESCO Regional Bureau for Education in Latin America and the Caribbean: Chile.

Patankar, P. (2011). Teacher Education: Need of Paradigm shift from Behaviorism to Constructivism. Indian Streams Research Journal, 1(11), 23-25.

Van Tassel-Baska, J., Quek, C. \& Feng, A. X. (2007). The development and use of a structured teacher observaiton scale to assess differentiated best practice. Roeper Review, 29(2), 84-92.
Walsh, K. (2013). When I say...triangulation. Medical Education, 47(9):866. https://onlinelibrary.wiley.com/doi/ full/10.1111/medu. 12241

Watts, M.,\&Schaur, G. (2011). Teaching and assessment methods in undergraduate economics: A fourth national quinquennial survey. The Journal of Economic Education, 42(3), 294-309.

Wijnen, M., Loyens, S. M. M., Wijnia, L., Smeets, G., Kroeze, M. J., \& Van der Molen, H. T. (2018). Is problem-based learning associated with students' motivation? A quantitative and qualitative study. Learning Environments Research, 21(2), 173-193. https:// doi.org/10.1007/s10984-017-9246-9

Yin, R. (2009). Case Study Research: Design and Methods (4 $4^{\text {th }}$ ed.). Sage Publications.

Citation: Rhonda Dookwah, Gabriel Julien “Students' experiences about PBL as theylearn Developmental Mathematics at a Higher Education Institution in Trinidad and Tobago: A qualitative case study". American Research Journal of Humanities and Social sciences, Vol 7, no. 1, 2021, pp. 1-8.

Copyright (c) 2021 Rhonda Dookwah et al., This is an open access article distributed under the Creative Commons Attribution License, which permits unrestricted use, distribution, and reproduction in any medium, provided the original work is properly cited. 